\title{
Development Patterns and Policy Suggestions for Cultural and Creative Industry Clusters
}

\author{
Wu Yuguang \\ Major in Industrial Economics, Shaanxi Normal University, Chang an District
}

\begin{abstract}
This paper reviews the classical theory of industrial clusters, including Smith's division of labor, the Marshallian industrial district industrial district, Alfred Weber's industrial location theory, the theory of new industrial zone, François Perroux 's theory of growth pole, Schumpeter's theory of technological innovation, Porter's theory of industrial clusters, and analyzes those classical theories. This paper lists some definitions of the concept of cultural industry cluster by domestic and foreign scholars, and classifies different cultural industry clusters into cultural convergence clusters, location factor clusters, vertical association clusters and horizontal association clusters. Based on the discussion of many scholars, the reasons for the formation of cultural creative industry clusters are summarized. Finally, the paper points out four development models of cultural and creative industries and puts forward the policy recommendations for the development of China's cultural and creative industry clusters according to the characteristics of cultural and creative industries and their influencing factors.
\end{abstract}

Keywords-Cultural innovation; Industrial cluster; Influence factors; Development model

\section{INTRODUCTION}

This article reviews the classical theory of industrial clusters, describes the concept and classification of cultural and creative industrial clusters, and analyzes the factors that influence the formation of cultural and creative industrial clusters. Learn from the development model of the cultural industry and propose policy recommendations for China's cultural and creative industries.

\section{REVIEW OF THE CLASSIC THEORY OF INDUSTRIAL CLUSTERS}

From the appearance of the phenomenon of human barter, the agglomeration of economic activities in the earth's space appeared. The related economic activities are gathered in the specific space range. The reasons, laws and characteristics of this economic phenomenon have aroused the discussion of many economists at home and abroad.

In March 1776, Adam Smith [1] put forward the viewpoint of division of labor for the first time in the "The Wealth of Nations", and systematically expounded the great role of the division of labor in increasing labor productivity and enhancing national wealth. Adam Smith saw the efficiency of the division of labor and professional production in the early stages of industrialization. He believes that the division of labor is the source of the increase in national wealth and the core phenomenon of economic life. Smith not only generally discussed that the way of division of labor can increase labor productivity, but also deeply analyzed the reasons for the efficiency of division of labor. He divides the division of labor into three types: one is the division of labor within the company; the second is the division of labor among enterprises, that is, the specialization of labor and production among enterprises; and the third is the division of labor in industry or the division of labor in society. The second form of division of labor is in essence the theoretical basis for the formation of enterprise clusters. It is precisely because of this division of labor, enterprise clusters will have efficiency advantages that neither a single enterprise nor the entire market can have. Overdivisional work and market division of labor have a series of drawbacks. The enterprise cluster ensures the efficiency of division of labor and specialization, and at the same time further deepens the division of labor and specialization, which in turn promotes the development of the enterprise cluster.

Alfred Marshall (1890) [2] was the first economist to pay attention to the phenomenon of industrial agglomeration. In Marshall's view, the most fundamental reason for these industries to gather in the industrial area is to obtain external economies of scale. Marshall thinks the external economy is very important. "This kind of economy can often be obtained by concentrating on a lot of enterprises of similar nature in a specific area, that is, the distribution of industrial areas commonly referred to". Marshall explained the three main reasons why a manufacturer concentrates more efficiently than a single isolated manufacturer: the concentration of vendors can promote the formation of a professional supplier team; the concentration distribution of the manufacturer is conducive to the sharing of the labor market; the concentration of the manufacturer contributes to the spillover of knowledge. The basic characteristics of industrial clusters are first derived from Marshall's understanding of the industrial area. Marshall defines the industrial area as a region limited by history and nature, among which small and medium enterprises are actively interacting with each other, and the enterprise group and the society tend to merge. Marshall believes that the industrial zone has 6 characteristics: 1 , the value system of the local community and the environment of synergistic innovation; 2 , the enterprise group with vertical connection; 3 , the optimal allocation of human resources; 4 , the ideal market in the industrial area: the incomplete competitive market; 5, competition and cooperation; 6, characteristic local credit system. 
Alfred Weber [3], a German economist, discussed the causes of the formation of industrial clusters in his 1909 work "industrial location theory" from the angle of cost saving brought by industrial agglomeration. He thinks that the lowest cost location is the best location, and aggregation can make the enterprise obtain cost savings. An increase in the size of an enterprise can bring benefits to the factory or save the cost, and a number of enterprise clusters can also bring more income or less cost to each enterprise in one place. The specialization of the development of technology and equipment, the reduction of the related cost of searching the labor force also promote the agglomeration of the enterprises. He regards the benefits brought by agglomeration as cost savings and increase in profits. It is precisely the cost savings that motivate enterprises to generate agglomeration. The development of professional market can improve the size of bulk purchase and the scale of sales, make the enterprises enjoy the convenience of purchasing raw materials and realize the trade of products smoothly, thus reducing the cost of enterprises and improving the efficiency. Enterprise agglomeration is conducive to the construction and sharing of infrastructure such as road, gas and tap water, thus reducing the recurrent cost of expenditure, thus promoting the agglomeration of enterprises.

The French economist Francois Peru [4] has put forward the growth pole theory. The theory of growth poles holds that a country must achieve balanced development is only an ideal, and it is impossible in reality. Economic growth is usually transmitted from one or several "growth centers" to other departments or regions. Therefore, we should choose a specific geographic space as a growth pole to drive economic development. The main point of this theory is that regional economic development mainly depends on a few areas and a few industries with better conditions. It should cultivate a small number of well-conditioned areas and a few well-conditioned industries into economic growth poles.

Michael Porter [5] pioneered the theory of industrial clusters under the global economy to view and analyze the phenomenon of industrial clusters from a new angle of viewcompetitiveness. Industrial clusters are playing an increasingly important role in the increasingly complex, knowledgeoriented and dynamic economies. Porter put forward the theory of "diamond system" formed by four key elements to analyze and study the phenomenon of the cluster from the perspective of competitiveness. The results showed that the cluster not only reduced transaction costs and improved efficiency, but also improved incentive methods to create collective wealth such as information, specialization, and reputation.

\section{THE CONCEPT AND CLASSIFICATION OF CULTURAL AND CREATIVE INDUSTRIAL CLUSTERS}

The concept of cultural and creative industrial clusters has not yet been defined in the academic community. Allen J. Scott [6] pointed out that the production of cultural industries has its own distinct characteristics, and therefore it also leads to a clear agglomeration trend of cultural and creative industries. Andy C. Pratt [7] defines cultural industrial clusters and points out that clustering is not a powerful tool for analyzing cultural industries. There are also a large number of scholars in China who define the concept of cultural industrial clusters. Lan Juanli and Lei Hongzhen [8] believe that industrial clusters refer to companies that are connected to each other in a specific area, coexist in the same competitive environment, and are geographically concentrated. Wang Jici [9] pointed out that innovation is a social process. Different disciplines and industries need to interact intensively to generate innovative results.This innovative environment based on the highly interactive local enterprises is the truth of the concept of industrial clusters. From the perspectives of industrial structure and product structure, Meng Laiguo and Li Xiangdong [10] hold that industrial clusters are actually the extension of the processing depth of a certain product and the extension of the industrial chain. From an industrial organization point of view, an industrial cluster is actually the vertical integration of enterprises or large companies and large enterprise groups within a certain area. Integrating the views of many scholars, the cultural industry cluster is established in the cultural industry field by relatively independent and simultaneously related cultural and creative enterprises and related supporting organizations, based on the specialization of division of labor and collaboration that are gathered in a certain area. The industrial organization includes all upstream and downstream companies in the cultural and creative industry chain.

It is generally believed that the cultural and creative industries can be divided into different types of clusters according to the formation reasons, cluster structure, and industry-related methods. Relevant scholars also started with different perspectives and different characteristics to classify cultural industrial clusters. Jiang Sangen [11] divided them into culturally convergent clusters and location factor clusters according to different causes. Based on the different development stages of the cluster, Wang Huimin [12] divides the cluster into cultural, creative, and creative areas in the initial stage, take-off stage, and mature stage. Kang Xiaoming and Xiang Yong [13] divide the cultural and industrial classification into three categories: core cultural industry clusters, peripheral cultural industrial clusters, and related support institutions. In general, the general classification includes the following four types: 1. Culturally convergent clusters: Culturally convergent clusters refer to clusters of creative industries that originate from a common cultural background, value concept, or institutional environment. 2 . Location-based clusters: Location-based clusters refer to the clustering of creative industries that originate from specific geographic locations, or close to special creative groups, or close to target consumer groups, or close to the trading market.3. Vertically-associated cluster: Vertically-associated industrial cluster refers to a multi-level industrial cluster in 
which upstream and downstream enterprises have a complex industrial group in which raw material supply, finished product or semi-finished product production, and sales of finished products are linked.4. Horizontally-associated clusters: Horizontally-related industrial clusters are essentially the same industrial group.

\section{FACTORS AFFECTING THE FORMATION OF CULTURAL AND CREATIVE INDUSTRY CLUSTERS}

Economic basis. People's demand for cultural and creative products is mainly to meet the direct demand for spiritual consumption or to increase the value-added production needs. It is a non-rigid demand with a relatively large elastic demand for income. Therefore, the economic basis is an important factor that influences the demand for cultural and creative products. The higher the level of economic development, the higher the proportion of residents' consumption structure used to satisfy cultural and spiritual needs, and the greater the demand for culturally creative products in this region.

Creative class. The cultural and creative industries are based on creativity and innovation as the fundamental elements and motivation, and the creativity comes from human intelligence and creative thinking. Marlet G, Woerkens CV [14] found that because of the concentration of Dutch business, financial services, and start-ups, the creative class can better predict regional economic growth represented by employment growth than education levels; Möller J and Tubadji A [15], Boschma R, and Fritsch M. [16] reached the same conclusion with the cases of German and European cities, respectively. Marlet G, Woerkens CV provided a reasonable explanation for this phenomenon: First, receiving a higher education does not mean that he or she is engaged in a job that matches his or her level of education, not even a job, and the creative class itself is working. The second reason is that two groups of people with the same level of education have different work efficiency in different work environments, and can get more inspiration through learning and face-to-face communication during the work of creative environment.

Intellectual property system. The creativity itself is easily copied. In the creative $R \& D$ phase, if the protection of intellectual property rights is weak, it will seriously damage the interests of the original creators, dampen the enthusiasm of original activities, and will seriously affect the progress of the core competitiveness of the entire industry. Zhao Yulin (2006) [17] believes that since intellectual property protection does not prevent thought inspiration, the safe presentation of an idea may inspire the creation of another or even more creative ideas. Therefore, cities must first establish a rational intellectual property system for the development of creative industries.

High-tech. The development and application of high and new technology can expand the main body of innovation so that consumers and product users can participate in the innovation activities of emerging industries, and further enhance the independent creative ability and original ability of cultural and creative industries. In addition to the accumulation of talents and the prosperity of the region itself, high-tech is also attracting the creative class in two aspects. First, consumer preferences are expressed in the creative class's enthusiasm for high-end, personalized, and diverse cultural products. The provision of these products requires a higher level of technical support; the second is job preferences, and the creative class is clearly biased towards concentration in knowledge-intensive industries. Lorenzen M, Andersen K V. [18] tested these two preferences of the creative class.

Cultural and creative enterprise financing model. Cultural and creative enterprises rely mainly on intangible assets such as human capital and intellectual property, and are light asset companies, often lacking tangible assets that can be used for mortgage guarantees. Domestic banks generally only accept real estate and liquid securities that are highly liquidated as collateral, which greatly limits the financing capacity of cultural and creative companies. Lack of effective financing channels will make it difficult for cultural and creative enterprises to break through the small-scale and decentralized state and make it difficult to become bigger and stronger. It is undoubtedly important to promote the development of the industry to establish a diversified and multi-level financing model for the characteristics of capital demand of cultural and creative companies.

Government function. The European and American cultural and creative industrial clusters are mainly based on the selforganizing process of the market mechanism, while most of the Asian countries and regions and their cultural and creative industrial clusters are largely formed under the guidance of the government. The government's role in the cultural and creative industries is mainly reflected in three aspects: The government's policy on cultural and creative industries planning and supporting will affect the supply of factors for the industry, and the government as a cultural and creative industry standard setter and product consumer will influence the industry's demand conditions, relevant laws and regulations formulated by the government will affect the competitive structure and corporate strategy of the cultural and creative industries.

\section{THE DEVELOPMENT MODEL OF CULTURAL AND CREATIVE INDUSTRIES}

Park district agglomeration development model. Terry Flew (2010) [19] believes that the reason is that Marshall's view challenges the "winner takes all" theory in neoclassical equilibrium theory. In the 1990s, the concept of industrial agglomeration was reintroduced by Professor Porter of Harvard Business School. Porter (1998) thought that industrial agglomeration could provide enterprises with three competitive advantages. The first is to promote productivity. Through the introduction of experts and professional skills workers, access to professional information, and industrial agglomeration, the complementary relationship between companies has developed rapidly. The second is to increase innovation opportunities. Industrial agglomeration brings the distance between producers closer together, and the internal communication within the industry makes the cost of producers converge. This environmental factor increases the pressure on producers to innovate. The third is the new business model. Industrial agglomeration makes it easier for companies to obtain the required information at the initial stage of market entry and reduces the barriers to market entry. 
Integrated development with other industries model. According to the development of the UK cultural and creative industries, Banks $M(2010)$ [20] believed that as cultural and creative industries are increasingly dependent on rival industrialists, how to train qualified artisans and related technical personnel is the key to the further development of cultural and creative industries. The earliest proposed introduction of cultural and creative elements in the traditional tourism industry was Pine B J, Gilmore J H [21] they believe that in the age of experiencing consumption, fierce competition among suppliers in the cultural tourism industry will guide them to take product supply to a new stage. Operators use creative methods and processes to create new economic values by guiding visitors to experience and improve themselves.

Market-oriented development model. This development model is characterized by the implementation of a free enterprise system, restricting monopoly, protecting free competition, reducing state administrative intervention, and strengthening macro guidance and public services. Therefore, in the British and American cultural and creative industries, especially in the British cultural and creative industries, SMEs accounted for the vast majority. Phil Wood, Calvin Taylor (2004) [22] referred to the British town of Huddersfield as the most representative. Huddersfield invited Charles Landry, the father of "City of Creativity", as a consultant to create a creative cycle system for the city. The core of the creative cycle system lies in the establishment of a cultural and creative market and a market system that makes full use of market efficiency.

Government-led development model. Japan, South Korea, Taiwan, Hong Kong, and Singapore are all government-led to develop cultural and creative industries and have achieved success. The above countries and regions have been able to become strong cultural and creative industries (regions) in a relatively short period of time. The implementation of the government-led development model is one of the most important reasons. The government-led development model is characterized by the government's strong intervention and leading role, playing the basic role of the market mechanism to allocate cultural resources, and at the same time assisted by government intervention.

\section{POLICY RECOMMENDATION}

According to the characteristics of the industry, the influencing factors of industrial agglomeration and the mode of development of various countries and regions, the following recommendations are made for the policy of China's cultural industry. For the developed coastal regions in the east, the market-oriented development model is more appropriate, and the marketization efficiency of these regions is also high. The central and western regions can adopt a government-led development model. This model makes good use of profound historical and cultural resources and achieves success in a relatively short period of time. After more than two decades of development, the competition in the modern cultural and creative industries has become increasingly fierce, and the market segmentation and professional division of labor have been increasingly strengthened. The governments of our country and regions should use their own resources and foundations, playing the basic role of the market mechanism to allocate cultural resources. At the same time, reasonable planning aims to achieve differentiated competition.

\section{CONCLUSION}

Generally speaking, the cultural and creative industries have its own characteristics. Developed countries have realized the prosperity of creative industries through marketization, and developing countries should use policies to promote the development of creative cultural industries. China has deep potential in using policies to promote the development of creative cultural industries.

\section{REFERENCES}

[1] Adam Smith. An inquiry into the Nature and Causes of the Wealth Volume (Volume 1) [M]. Beijing:The Commercial Press, 2010. (In Chinese)

[2] Marshall A. Principles of Economics [M]. London Macmillan, 1980.

[3] Alfred Weber. Industrial Location Theory [M]. Beijing: The Commercial Press, 1997. (In Chinese)

[4] Li rengui. Study on Growth Pole Theory and Policy in Regional Economic Development [J]Economic Research Journal,1988(9):63-70. (In Chinese)

[5] M.Porter. Cluster and New Economics of Competition. [M] New York Free Press, 1998.

[6] Allen J.Scott. Cultural-Products Industries and Urban Economic Development: Prospects for Growth and Market Contestation in Global Context. [J] Urban Affairs Review. 2004

[7] Andy C.Pratt. Creative Clusters: Towards the governance of the creative industries production system? [J] Media International Australia incorporating Culture and Policy 2004。

[8] Lan Juanli, Lei Hongzhen. Analysis on Evolutionary Game of Cooperation among Industrial Cluster Enterprises Based on Knowledge Spillover[J].Technology Economics,2015,34(03):1-6. (In Chinese)

[9] WANG Ji-ci. Differentiating Industrial Proximity and Agglomeration in the Development of Clusters and Parks [J]. China Soft Science,2005(12):91-98. (In Chinese)

[10] Meng laiguo, Li Xiangdong. Characteristics, Problems and Countermeasures of Cluster Development of Cultural Industrial Parks in Western China[J].Academic Exchange,2012(03):116-119.(In Chinese)

[11] Jiang sangen. The Development Types and Characteristics of Cultural and Creative Industrial Clusters in the Central Business District[J].Research on Economics and Management,2009(03):83-86. (In Chinese)

[12] Wang Huimin. Research on the Development of Shanghai Creative Industries Clusters[J].Journal of Social Sciences,2012(07):31-39. (In Chinese)

[13] Kang Xiaoming, Xiang Yong. Industrial Clusters and Promotion of Cultural Industry Competitiveness[J].Journal of Peking University(Philosophy and Social Sciences),2005(02):17-21. ( In Chinese)

[14] Marlet G, Woerkens C V. Skills and Creativity in a Cross-section of Dutch Cities [J]. Working Papers, 2004, 04.

[15] Möller J, Tubadji A. The Creative Class, Bohemians and Local Labor Market Performance A Micro-data Panel Study for Germany 1975-2004: Sonderausgabe Heft 2+3/Bd. 229 (2009) Jahrbücher für Nationalökonomie und Statistik [M]// Labour Economics. 2009.

[16] Boschma R, Fritsch M. Creative Class and Regional Growth - Empirical Evidence from Eight European Countries[C]// Friedrich-SchillerUniversity Jena, Max-Planck-Institute of Economics, 2007:391-423.

[17] Zhao Yulin. Innovation Economics[M].Beijing: China Economic Publishing House, 2006. (In Chinese)

[18] Lorenzen M, Andersen K V. Centrality and Creativity: Does Richard Florida's Creative Class Offer New Insights into Urban Hierarchy? [J]. Economic Geography, 2009, 85(4):363-390. 
[19] Terry Flew. Toward a Cultural Economic Geography of Creative Industries and Urban Development: Introduction to the Special Issue on Creative Industries and Urban Development [J]. Information Society, 2010, 26(2):85-91.

[20] Banks M, Bilton C. Craft labour and creative industries [J]. International Journal of Cultural Policy, 2010, 16(3):305-321.

[21] Pine B J, Gilmore J H. The experience economy [M]. 1999.

[22] Phil Wood, Calvin Taylor. Big ideas for a small town: the huddersfield creative town initiative [J]. Local Economy, 2004, 19(4):380-395. 